Madhusanka, N., Pan, W. and Kumaraswamy, M., 2019. Mapping and improving sustainable construction management through social network analysis: A review. In: Sandanayake, Y.G., Gunatilake, S. and Waidyasekara, A. (eds). Proceedings of the $8^{\text {th }}$ World Construction Symposium, Colombo, Sri Lanka, 8-10 November 2019, pp. 442-452. DOI: doi.org/10.31705/WCS.2019.44. Available at: https://2019.ciobwcs.com/papers

\title{
MAPPING AND IMPROVING SUSTAINABLE CONSTRUCTION MANAGEMENT THROUGH SOCIAL NETWORK ANALYSIS: A REVIEW
}

\author{
Nandun Madhusanka ${ }^{1}$, Wei Pan ${ }^{2}$ and Mohan Kumaraswamy ${ }^{3}$
}

\begin{abstract}
Social Network Analysis (SNA) has been used in multidisciplinary research during the past two decades due to the unique nature of network visualisation and extensive analytical capabilities. This tool has also gained increasing attention among the researchers in the sustainable construction arena in recent years. Nevertheless, a thorough review has not yet been done to review the application of SNA in the sector of sustainable construction. This paper attempts to address this gap through a comprehensive review of previous journal publications. Accordingly, 73 journal papers were initially identified for review through the "Web of Science "publications database. Subsequently, a bibliometric analysis was done through "VOS viewer" software package to identify the research trends throughout the past years. The results show significant progress in relevant publications during 2014-2018 and a major contribution to research from China. After an extensive filtration process, 17 particularly relevant journal papers were identified which have applied both social network visualisation and analysis techniques for the sustainability aspects of construction. The contents of these papers were comprehensively analysed in terms of data collection methods, network analysis techniques, network structures and sustainability knowledge areas. Finally, this paper contributes to theoretical knowledge in this domain, by suggesting a future research direction through a SNA conceptual model to analyse stakeholder collaborations for project life cycle sustainability initiatives. The findings of this paper will serve as a good source for future researchers to comprehensively identify, compare and contrast the applications of SNA techniques for sustainability related studies in the construction sector.
\end{abstract}

Keywords: Social Network Analysis; Sustainable Construction; Sustainability.

\section{INTRODUCTION}

Heightened attention to partnerships and collaborative arrangements among different entities in the construction sector is apparent through numerous recent studies (e.g. Manley, 2002; Kumaraswamy et al., 2010; De Silva et al., 2017). Accordingly, Scott et al. (2008) highlighted the importance of developing collaborative networks to visualise and analyse the connectedness of entities. The widely accepted and practiced theoretical foundation for mapping and assessing collaborative networks is the theory of Social

\footnotetext{
${ }^{1}$ Department of Civil Engineering, The University of Hong Kong, Hong Kong, nandun@hku.hk

2 Department of Civil Engineering, The University of Hong Kong, Hong Kong, wpan@hku.hk

${ }^{3}$ Department of Civil Engineering, The University of Hong Kong, Hong Kong, mohan@hku.hk
} 
Network Analysis (SNA) which provides a holistic picture and enhanced capabilities to analyse complex interactions in construction projects (Borgatti and Foster, 2003). Scholars have largely incorporated SNA techniques in studying construction management practices during the past two decades and some authors have comprehensively reviewed the applications of SNA in the construction sector (Chinowsky and Taylor, 2012; Zheng et al., 2016; Lee et al., 2017). "Sustainable Construction" targets on maximising the economic value of construction projects while minimising the negative effects on the environment and society ( $\mathrm{Wu}$ et al., 2018). With the rising attention to improving sustainability practices in the construction sector, scholars have progressively used SNA to develop collaborative networks and generate significant outcomes to improve and manage sustainability in construction. An in depth review of these publications can benefit scholars to identify prevailing knowledge areas and inspire future research directions. Yet, a comprehensive review has not been employed to specifically identify how SNA has been utilised to map and improve sustainability in the construction sector. Hence, this paper aims to address the aforementioned knowledge gap by employing a "bibliometric review" and a "review of SNA methods". As a final point, a SNA based future research direction is suggested focusing on stakeholder collaborations for life cycle sustainability initiatives.

\section{SOCIAL NETWORK ANALYSIS (SNA)}

\subsection{SNA AS A MANAGEMENT TOOL}

A typical network structure consists of nodes (actors/vertices) to represent entities and ties (a link, which is represented by a line connecting two nodes in a network) to represent the connectedness between entities (refer Figure 1) (Lee et al., 2017). Establishing this network necessitates identifying significant entities within the network and establishing relationships among identified entities focusing on a desired goal or a set of goals (Alves et al., 2012).

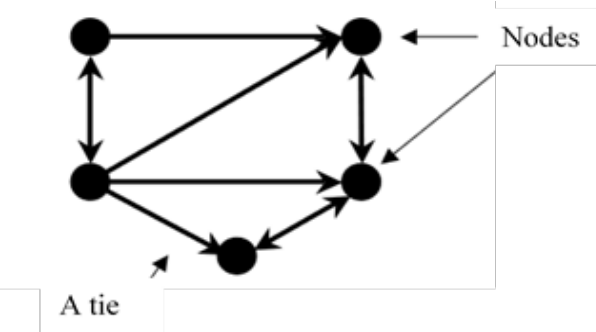

Figure 1: The structure of a social network

Initial thoughts about SNA go back to the 1930s and SNA theories have been primarily utilised to investigate informal relationships of social groups during the early stages of SNA adaption (Zheng et al., 2016). SNA applications for the development of organisational networks have been evident from late 1970s (Kilduff and Tsai, 2003). During this period, researchers started to use SNA theories for empirical management studies within business organisations by developing social network structures to visualise formal relational arrangements at organisational level (Tichy et al., 1979). After this era, an upsurge in SNA related studies is observed, largely due to the development of software based platforms with commanding network analysis tools such as UCINET, PAJEK and NETMINER (Bodin and Crona, 2009). A number of studies related to the areas like knowledge management, medicine, risk management, information and communication 
technology, project management, organisational management, supply chain management, etc. can be identified during the past two decades (Vechan, 2015; Lee et al., 2017).

\subsection{SNA IN CONSTRUCTION MANAGEMENT}

The application of SNA in the fields of construction management began gaining the attention of scholars during the period of 1990s (Vechan, 2015). Early studies mainly focused on the network development and analysis of intra- organisational level stakeholders in construction project environments (Loosemore, 1997). Thereafter, the studies of SNA in construction management mainly focused on the areas like analysing cross boundary relationships of organisations and stakeholders, representation of the organisational structure of projects, stakeholder associated risk management in project environments, project governance, stakeholder communication networks and health and safety management (Pryke, 2012; Zheng et al., 2016; Lee et al., 2017). Nowadays, the project environments have become more complex, hence practices and procedures are significantly affected by sociological and institutional policies and changes. Therefore, recent SNA related studies have also considered the entities in external environment and sociological factors (Chinowsky and Taylor, 2012).

\section{BIBLIOMETRIC REVIEW OF SNA APPLICATIONS IN SUSTAINABLE CONSTRUCTION MANAGEMENT}

\subsection{REVIEW METHODS}

For the bibliometric review, a database search was done to identify the previous journal publications related to the applications of SNA in sustainable construction by adapting a methodical process proposed by $\mathrm{Hu}$ et al. (2013) which discusses the key procedures in assessing the contents of previous publications. Accordingly, as the initial step, a comprehensive exploration was done through the "Web of Science" database "Topic Search" function using the keywords "Social Network Analysis" and "Sustainable Construction" which resulted in 73 journal publications during 2005 to 2018 (Figure 2). "Web of Science" is one of the largest publications databases in the world which provides access to a range of citation indexes. During the "Topic Search" function, the database searches through all the words in title, abstract and the keywords in an article to match and identify the related publications. Hence, the researchers were able to access nearly all the best matching journal publications for the intended review. Subsequently, the search results were further analysed through "VOS viewer" bibliometric analysis software package to construct the keyword co-occurrence network and co-citation network.

\subsection{REVIEW RESULTS}

"Web of Science" database search results emphasised a rising attention for SNA related studies in the arena of sustainable construction management. From 2005 to 2010, the number of papers published was less (9 papers) when comparing with the publications after the year 2010. Further, 58 (out of all 73) papers were published during the period of 2014-2018 (refer Figure 2). This emphasises that SNA has become a more popular analytical tool among the researchers in sustainable construction sector during the recent years. 


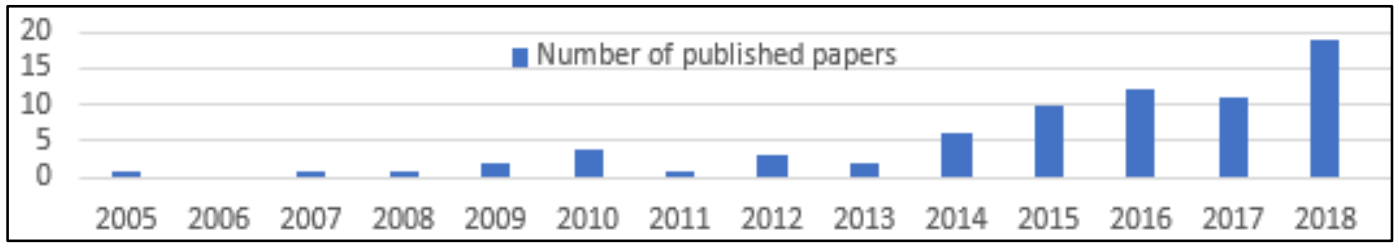

Figure 2: Number of journal publications for the application of SNA in sustainable construction

\subsubsection{Keywords and Citations Distribution}

Keywords co-occurrence network and co-citation network were developed to further understand the trends of SNA applications in the arena of sustainable construction management. The minimum number of occurrences of a key word was set to 5 times to reduce the complexity which resulted in a network of 16 frequently appeared keywords out of 589 total keywords. Network "A" in Figure 3 shows all 16 keywords where node sizes are arranged according to the frequency of occurrences and total strength of the cooccurrence links are visualised through line weightages. Three main keyword clusters were identified (Nodes with Red, Green and Blue) which had close co-occurrences with each other in the identified set of publications.

Network "B" in Figure 3 was developed to understand the research trends over time. Thus, the keywords related to primary database search (SNA-16 occurrences, construction-16 occurrences, sustainability-11 occurrences, sustainable development-9 occurrences) were removed from the network to clearly identify the changing pattern of topics from 2010 to 2018. Comparative analysis of node colours with the provided time scale in network "B" shows that the topics; "Innovation", "Risk", "Evolution" and "Policy" attracted rising attention recently. Interestingly, the keyword "China" also showed a heightened attention during this period, which testifies to the many significant applications in the region.

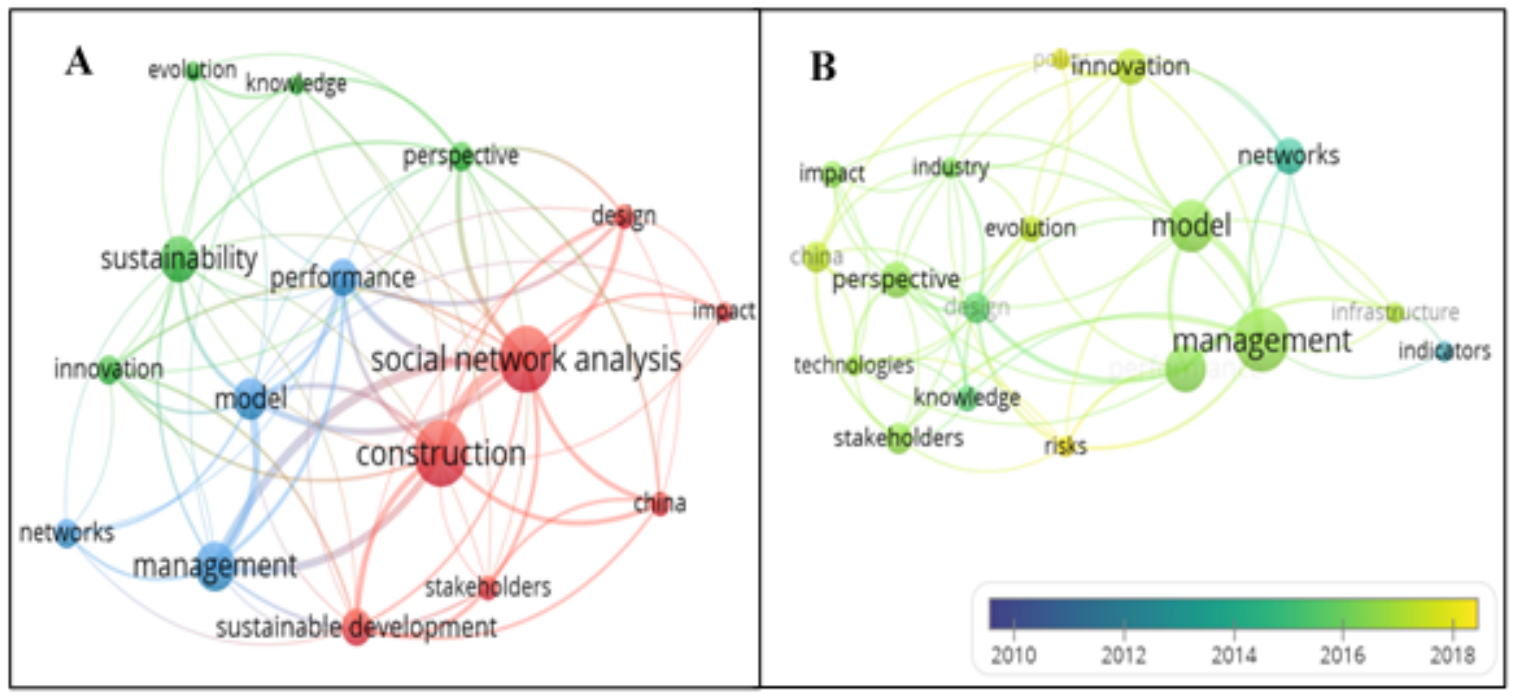

Figure 3: Keyword co-occurrence networks

For co-citation network, minimum number of publications threshold was set to 3 documents for a country. Accordingly, 10 countries appeared, while countries outside the main co citation cluster were excluded which resulted in a network of 6 countries with most number of co citations (refer to the network in Figure 4). Node sizes of the network are arranged according to the number of publications for each country. Node colours 
represent the time scale of publications while link weightages represent the frequency of co-citations. China leads with the highest number of publications ( 15 papers) in the field and the strongest co-citation link is shown between Australia and China. Further, the pie chart in Figure 4 emphasises the percentage number of publications for each country, out of the set of identified journal publications. All the aforementioned findings point to a rising attention in the use of SNA for the management and improvement of sustainable construction in the region of China.

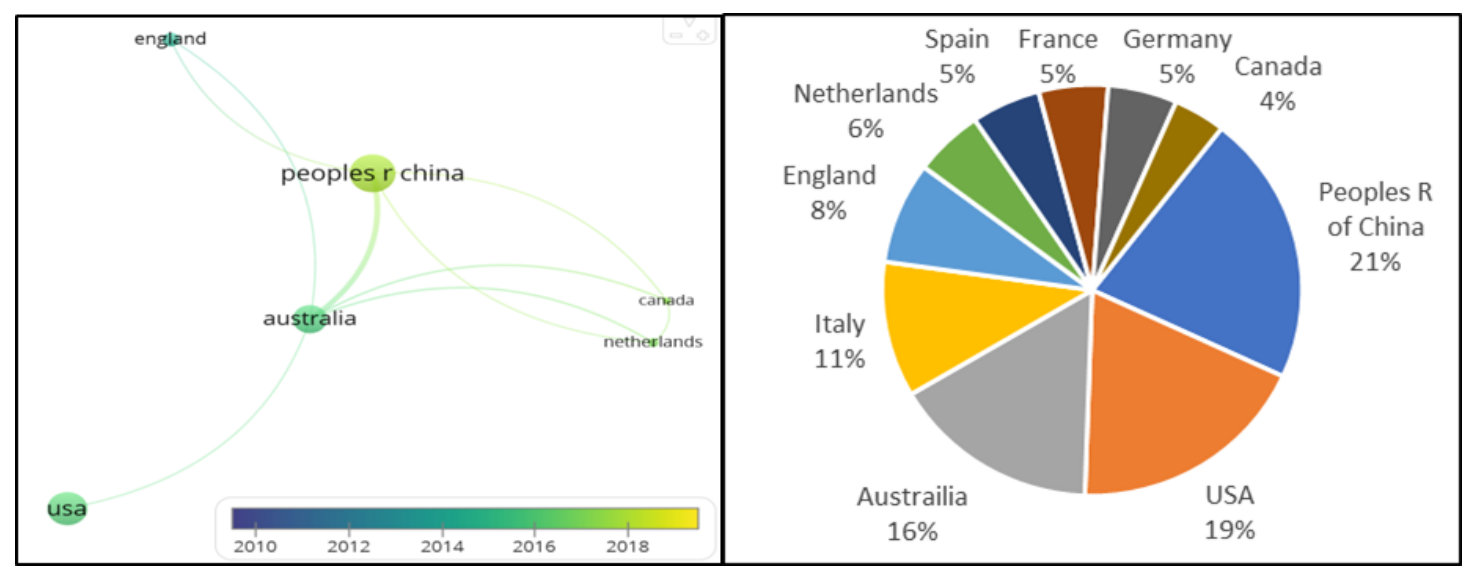

Figure 4: Co-citation network and percentage of publications

\section{REVIEW OF SNA METHODS USED IN SUSTAINABLE CONSTRUCTION MANAGEMENT}

\subsection{REVIEW METHODS}

This section is focused on comprehensively analysing the SNA methods employed in the field of sustainable construction. Therefore, the initial set of 73 publications were analysed to filter and identify the most relevant papers. Even though most of the papers showed the application of SNA theories and discussions, there were only 17 papers which constructed social network matrices through data collection processes and employed SNA quantitative methods. Though the number of papers was less, the most appropriate studies were identified to perform the intended review. The following sections describe the data collection methods, analysis techniques, network structures, knowledge areas and significant outcomes of SNA related studies in the field of sustainable construction.

\subsection{REVIEW RESULTS}

\subsubsection{Data Collection Methods Used to Identify Nodes and Links for Social Networks}

Identification of nodes and links are the main two facets in data collection essential to develop social network structures (Borgatti, 2013). Researchers use different types of techniques for the data collection in SNA related studies such as interviews, observations, surveys and data mining (Wasserman and Faust, 1994). Figure 5 shows a comparative representation of data collection methods utilised to identify nodes and links in the selected 17 papers. Literature findings, questionnaire surveys and interviews are frequently used for the identification of nodes while questionnaire surveys, workshops and interviews are commonly used to identify the links. 


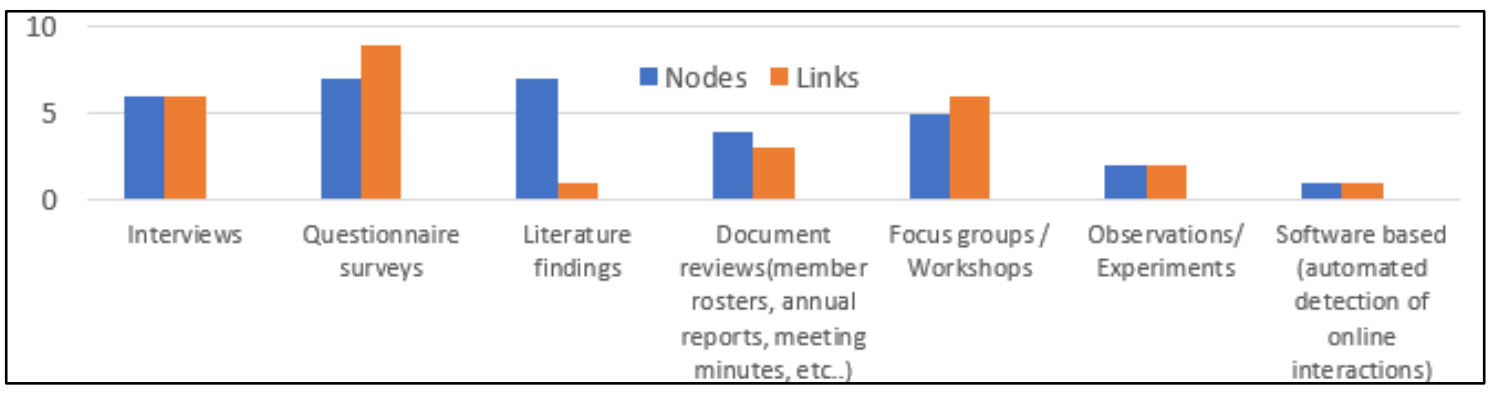

Figure 5: A comparison of data collection methods for nodes and links

\subsubsection{Social Network Quantitative Analysis Methods}

Scholars have utilised numerous social network based quantitative analysis methods to interpret their findings in different contexts. Among the diverse methods, Centrality and Density measures are frequently used and popular among scholars (Lee et al., 2017; Butts, 2018). The publications reviewed in the current study also have incorporated a number of different social network based quantitative analysis techniques. Most of the studies have adapted multiple measures depending on the projected outcomes. Thus, Table 1 shows the frequently used quantitative analysis methods in the reviewed 17 papers with the number of occurrences and a brief description of the respective method.

Table 1: SNA quantitative measures

\begin{tabular}{|c|c|c|}
\hline SNA method & $\begin{array}{c}\text { Times } \\
\text { used }\end{array}$ & Description (Wasserman and Faust, 1994; Loosemore, 1998) \\
\hline Degree centrality & 14 & Measures the level of connectivity of a node (Number of links) \\
\hline $\begin{array}{l}\text { Betweenness } \\
\text { centrality }\end{array}$ & 13 & $\begin{array}{l}\text { Measures the extent which a node lies between other nodes. (A } \\
\text { higher value indicates a better control over the information/ } \\
\text { impact passing across the node) }\end{array}$ \\
\hline Network density & 7 & Ratio of the number of ties to the maximum possible ties. \\
\hline Out degree & 7 & Number of out coming connections from a node (impact to) \\
\hline In degree & 6 & Number of incoming connections to a node (impacted by) \\
\hline $\begin{array}{l}\text { Closeness } \\
\text { centrality }\end{array}$ & 6 & $\begin{array}{l}\text { Measures the score of each node based on the length of the } \\
\text { path to all other nodes by calculating the shortest paths }\end{array}$ \\
\hline Degree difference & 3 & Difference between the in-degree and out-degree values \\
\hline
\end{tabular}

\subsubsection{Social Network Structures}

Most of the existing studies show the links between same type of nodes in networks which are referred as one mode networks (e.g. "actor - actor", refer to Network 1 in Figure 6). Further, there are some studies with two different types of entities which are identified as two mode networks (e.g. "actor-event", refer to Network 3 in Figure 6) (Borgatti, 2009; Pryke, 2012). Networks with more than two different types of nodes are less in practice due to limited analysis capabilities. Moreover, several studies can be identified which assigned the combined effect of two entities as a node in one mode networks (refer to Network 2 in Figure 6) 


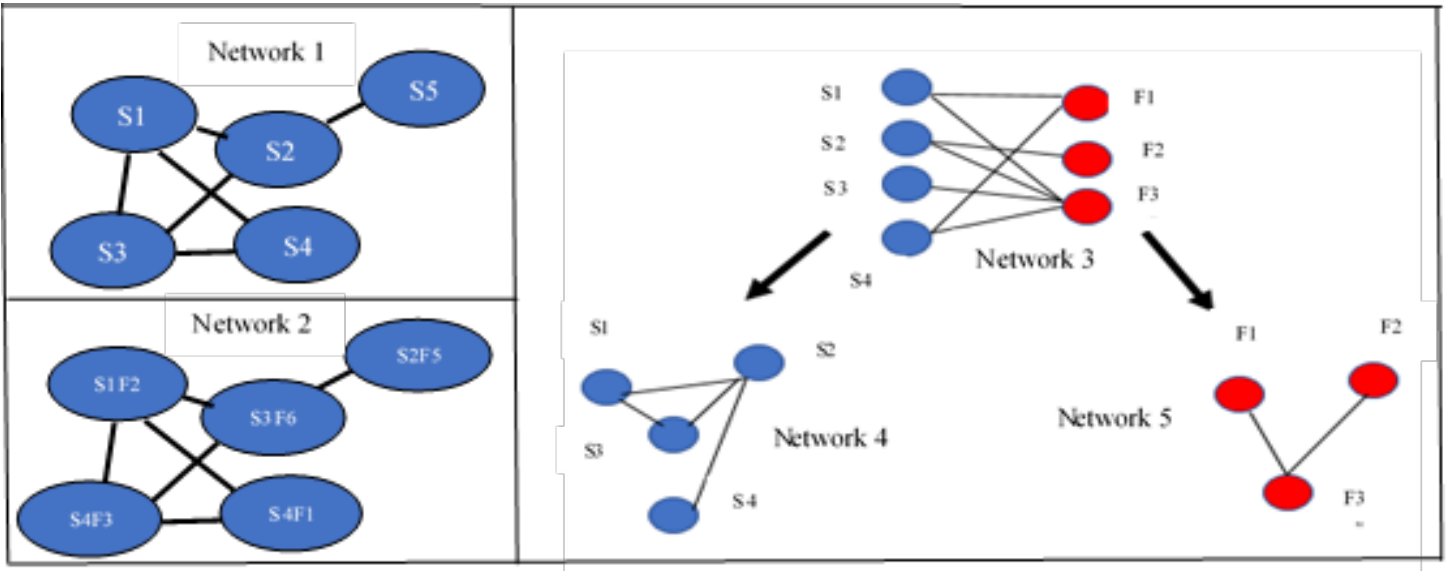

Figure 6: Network structures

To feed data into a network, a network analysis matrix should be prepared to identify interrelations among nodes, which is known as the adjacency matrix. These "actor-event" adjacency matrices can be converted into "actor-actor" and "event-event" matrices considering whether a pair of actors are associated with the similar event or whether two events are related with each other through a common actor (Borgatti, 2009; De Nooy et al., 2011). Accordingly, two mode networks can be converted to one mode networks to explore the unseen relationships and results (refer to Networks 3, 4, and 5 in Figure 6)

\subsubsection{Sustainability Knowledge Areas and SNA Applications}

Table 2 shows the applications of aforementioned network arrangements (Figure 6) in the reviewed papers. Studies 1 to 9 utilised the structure of Network 1 while studies 10-12 and 13-15 used the structures of Networks 2 and 3 respectively. Further, two-mode to one-mode conversion and analysis techniques can be identified in the studies 16 and 17.

Table 2: Sustainability knowledge areas and SNA applications

\begin{tabular}{|c|c|c|c|}
\hline & Authors & Areas & Applications and outcomes of SNA \\
\hline 1. & $\begin{array}{l}\text { Zedan and } \\
\text { Miller } \\
(2017)\end{array}$ & $\begin{array}{l}\text { ergy } \\
\text { nagement }\end{array}$ & $\begin{array}{l}\text { To visualise strongly linked stakeholders and information } \\
\text { dissemination patterns influencing energy efficiency. }\end{array}$ \\
\hline 2. & $\begin{array}{l}\text { Li et al. } \\
\text { (2017) }\end{array}$ & y & $\begin{array}{l}\text { To assess stakeholder engagement and communication } \\
\text { for the effective implementation of net zero energy } \\
\text { homes }\end{array}$ \\
\hline 3. & $\begin{array}{l}\text { El-Diraby et } \\
\text { al. (2017) }\end{array}$ & $\begin{array}{l}\text { Green } \\
\text { buildings/ } \\
\text { technologies }\end{array}$ & $\begin{array}{l}\text { To visualise online stakeholder interactions in a Building } \\
\text { Information Modelling (BIM) platform to identify } \\
\text { patterns of green information communication. }\end{array}$ \\
\hline & $\begin{array}{l}\text { Xue } \text { et al. } \\
(2018)\end{array}$ & $\begin{array}{l}\text { Economical } \\
\text { sustainability }\end{array}$ & $\begin{array}{l}\text { To assess the stakeholder collaborative arrangements to } \\
\text { compare with cost performances of projects. }\end{array}$ \\
\hline 5. & $\begin{array}{l}\text { Schröpfer } e t \\
\text { al. }(2017)\end{array}$ & $\begin{array}{l}\text { Knowledge } \\
\text { management }\end{array}$ & $\begin{array}{l}\text { To map the knowledge flow among stakeholders related } \\
\text { to sustainable techniques, technologies and materials. }\end{array}$ \\
\hline 6. & $\begin{array}{l}\text { Wang et al. } \\
(2018)\end{array}$ & $\begin{array}{l}\text { Social } \\
\text { sustainability }\end{array}$ & $\begin{array}{l}\text { To visualise stakeholder interactions for the improvement } \\
\text { of social sustainability in construction }\end{array}$ \\
\hline 7. & Doloi (2012) & $\begin{array}{l}\text { Social } \\
\text { sustainability }\end{array}$ & $\begin{array}{l}\text { To identify most influencing stakeholders for the social } \\
\text { performance of infrastructure projects }\end{array}$ \\
\hline
\end{tabular}




\begin{tabular}{|c|c|c|}
\hline Authors & Areas & Applications and outcomes of SNA \\
\hline $\begin{array}{l}\text { 8. Cross et al. } \\
\text { (2017) }\end{array}$ & $\begin{array}{l}\text { Social/Energy } \\
\text { performance }\end{array}$ & $\begin{array}{l}\text { To assess the centralised participants and to identify the } \\
\text { knowledge and information flow across the network. }\end{array}$ \\
\hline $\begin{array}{l}\text { 9. Korkmaz } \\
\text { and Singh } \\
(2012)\end{array}$ & $\begin{array}{l}\text { Knowledge } \\
\text { management }\end{array}$ & $\begin{array}{l}\text { To analyse team interactions of student teams leaning } \\
\text { sustainable construction practices }\end{array}$ \\
\hline $\begin{array}{l}\text { 10. Wu et al. } \\
\text { (2018) }\end{array}$ & $\begin{array}{l}\text { All pillars of } \\
\text { sustainability }\end{array}$ & $\begin{array}{l}\text { To assess the network of stakeholder associated } \\
\text { indicators for evaluating mega sustainable construction } \\
\text { projects }\end{array}$ \\
\hline $\begin{array}{l}\text { 11. Yang and } \\
\text { Zou (2014) }\end{array}$ & $\begin{array}{l}\text { Green } \\
\text { buildings/Risk }\end{array}$ & $\begin{array}{l}\text { To map the interactions and assess stakeholder associated } \\
\text { risks in complex green building projects }\end{array}$ \\
\hline $\begin{array}{l}\text { 12. Yang et al. } \\
\text { (2016) }\end{array}$ & $\begin{array}{l}\text { Green } \\
\text { buildings/Risk }\end{array}$ & $\begin{array}{l}\text { To understand key risk networks by modelling networks } \\
\text { of stakeholder associated risks in green building projects }\end{array}$ \\
\hline $\begin{array}{l}\text { 13. Almahmoud } \\
\text { and Doloi } \\
\text { (2015) }\end{array}$ & $\begin{array}{l}\text { Social } \\
\text { sustainability }\end{array}$ & $\begin{array}{l}\text { To map and assess the relationships between } \\
\text { stakeholders and social core functions }\end{array}$ \\
\hline $\begin{array}{l}\text { 14. Liang et al. } \\
\text { (2015) }\end{array}$ & $\begin{array}{l}\text { Green } \\
\text { retrofits }\end{array}$ & $\begin{array}{l}\text { To map and assess the interactions between stakeholders } \\
\text { and critical success factors for green retrofits. }\end{array}$ \\
\hline $\begin{array}{l}\text { 15. Coles et al. } \\
\text { (2016) }\end{array}$ & $\begin{array}{l}\text { Energy } \\
\text { management }\end{array}$ & $\begin{array}{l}\text { To analyse the linkage between energy efficient } \\
\text { microgeneration installations for buildings and associated } \\
\text { organisations }\end{array}$ \\
\hline $\begin{array}{l}\text { 16. Yuan et al. } \\
\text { (2018) }\end{array}$ & $\begin{array}{l}\text { Social risk } \\
\text { management }\end{array}$ & $\begin{array}{l}\text { To assess the relationships between stakeholders and } \\
\text { social risks in construction projects }\end{array}$ \\
\hline $\begin{array}{l}\text { 17. Xiaodong et } \\
\text { al. (2018) }\end{array}$ & $\begin{array}{l}\text { Green } \\
\text { buildings }\end{array}$ & $\begin{array}{l}\text { To map the factors affecting green residential building } \\
\text { projects with project phases and analyse the connectivity } \\
\text { between the factors by converting to one- mode networks }\end{array}$ \\
\hline
\end{tabular}

\section{A FUTURE RESEARCH DIRECTION}

The focused review of existing publications exhibited an increasing demand in SNA applications for stakeholder management in the sustainable construction sector. Yet, a lack of concern can be observed for two-mode network approaches (as described in section 4.2.3). Further, most of the studies overlook the stakeholder relationships and interdependencies without considering coalitions in different project life cycle phases (refer Table 2). Thus, a conceptual model is suggested which can be effectively utilised to visualise and analyse the integration of stakeholders with project life cycle phases focusing sustainability initiatives (refer Figure 7). This model presents a two-mode network approach with meaningful one mode conversions and analysis pathways. 


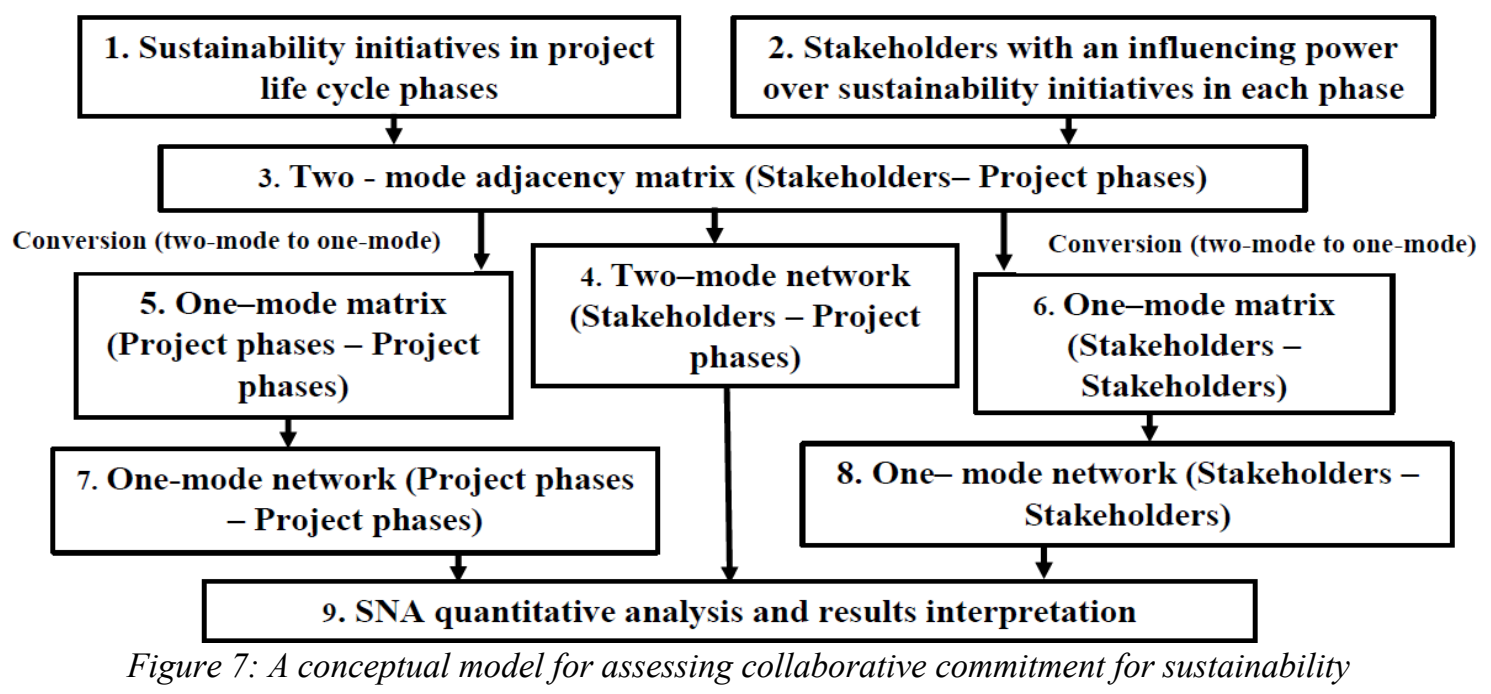

\section{CONCLUSIONS}

A critical review of the existing literature revealed an increasing demand in SNA applications for mapping and improving sustainability in the construction sector. The bibliometric analysis results indicate a rising attention in China followed by USA and Australia. Subsequently, a deeper understanding of collaborative arrangements of various entities can be derived through extensive SNA measures like Centrality and Density. The review results show that researchers have utilised the network structures in numerous ways to achieve intended outcomes and the use of SNA one-mode structures is seen to be more popular than two-mode and multi-mode structures. Results further emphasised that SNA has been widely utilised in the sustainability knowledge areas like Green Construction, Energy Management and Social Sustainability. Lastly, the proposed conceptual model provides an effective platform to analyse stakeholder collaborations for life cycle sustainability initiatives. Although, SNA provides a comprehensive platform to analyse collaborative arrangements, effective data collection on the relational aspects of each node is critical for the accuracy of network development. Inaccuracy of the relational attributes of one node can significantly affect the overall network structure and outcomes. Nevertheless, SNA has provided a valuable contribution for mapping and improving the sustainable construction management. This paper enhances the existing knowledge by providing a structured review of the application of SNA in sustainable construction practices and suggesting a future research direction with a novel conceptual model. The outcomes will benefit future researchers in this field to identify previous applications and build up effective research focus areas; and also assist practitioners in gaining an overview of their present interactions in pursuing sustainable construction and also indicating any duplication, gaps or other weak areas to be addressed, so as to increase the effectiveness and efficiency of their sustainability endeavours.

\section{REFERENCES}

Almahmoud, E. and Doloi, H. K., 2015. Assessment of social sustainability in construction projects using social network analysis, Facilities, 33, pp.152-176.

Alves, H., Raposo, M., and Wagner, E., 2012. A model for stakeholder classification and stakeholder relationships, Management Decision, 50(10), pp.1861-1879.

Bodin, Ö. and Crona, B. I., 2009. The role of social networks in natural resource governance: What relational patterns make a difference?. Global Environmental Change, 19, pp.366-374. 
Borgatti, S. P., 2013. Analyzing social networks, Los Angeles: Sage.

Borgatti, S.P., 2009. Social network analysis: Two-Mode Concepts. In R. Meyers (ed.), Encyclopaedia of Complexity and Systems Science, Springer: New York.

Borgatti, S.P. and Foster, P.C., 2003. The network paradigm in organizational research: a review and typology. Journal of Management, 29(6), pp.991-1013.

Butts, C. T., 2008. Social network analysis: A methodological introduction. Asian Journal of Social Psychology, 11, pp.13-41.

Chinowsky, P. and Taylor, J.E., 2012. Networks in engineering: an emerging approach to project organization studies. Engineering Project Organization Journal, 2(1/2), pp.15-26.

Coles, A.M., Piterou, A. and Genus, A., 2016. Sustainable energy projects and the community: Mapping single-building use of microgeneration technologies in London. Urban Studies, 53, pp.1869-1884.

Cross, J., Shelley, T. and Mayer, A., 2017. Putting the green into corrections: Improving energy conservation, building function, safety and occupant well-being in an American correctional facility. Energy Research and Social Science, 32, pp.149-163.

De Nooy, W., Mrvar, A. and Batagelj, V., 2011. Exploratory Social Network Analysis with Pajek, Cambridge University Press: Cambridge.

De Silva, N., Weerasinghe, R., Madhusanka, H., and Kumaraswamy, M., 2017. Relationally integrated value networks (RIVANS) for total facilities management (TFM). Built Environment Project and Asset Management, 7(3), pp.313-329.

Doloi, H., 2012. Assessing stakeholders' influence on social performance of infrastructure projects. Facilities, 30, pp.531-550.

El-diraby, T., Krijnen, T. and Papagelis, M., 2017. BIM-based collaborative design and socio-technical analytics of green buildings. Automation in Construction, 82, pp.59-74.

Hu, Y., Chan, A.P., Le, Y. and Jin, R.Z., 2013. From construction megaproject management to complex project management: Bibliographic analysis. Journal of management in engineering, 31(4), p.04014052.

Kilduff, M. and Tsai, W., 2003. Social Networks and Organizations, London: Sage.

Korkmaz, S. and Singh, A., 2012. Impact of Team Characteristics in Learning Sustainable Built Environment Practices. Journal of Professional Issues in Engineering Education and Practice, 138, pp.289-295.

Kumaraswamy, M. M., Anvuur, A. M. and Smyth, H. J., 2010. Pursuing "relational integration" and "overall value" through "RIVANS". Facilities, 28, pp.673-686.

Lee, C.Y., Chong, H.Y., Liao, P.C. and Wang, X., 2017. Critical review of social network analysis applications in complex project management. Journal of Management in Engineering, 34(2), p.04017061.

Li, H., Patel, D., Al-Hussein, M., Yu, H. and Gül, M., 2018. Stakeholder studies and the social networks of NetZero energy homes (NZEHs). Sustainable Cities and Society, 38, pp.9-17.

Liang, X., Shen, G. Q. and Guo, L., 2015. Improving Management of Green Retrofits from a Stakeholder Perspective: A Case Study in China. International Journal of Environmental Research and Public Health, 12, pp.13823-13842.

Loosemore, M., 1997. Construction crises as periods of social adjustment. Journal of Management in Engineering, 13(4), pp.30-37.

Loosemore, M., 1998. Social network analysis: using a quantitative tool within an interpretative context to explore the management of construction crises. Engineering, Construction and Architectural Management, 5(4), pp.315-326.

Manley, K., 2002. Partnering and Alliancing in road projects in Australia and internationally. Road and transport research, vol. 11, no. 3, pp. 46-60.

Pryke, S., 2012, Social Network Analysis in Construction, UK: Wiley-Blackwell.

Schröpfer, V. L. M., Tah, J. and Kurul, E., 2017. Mapping the knowledge flow in sustainable construction project teams using social network analysis. Engineering, Construction and Architectural Management, 24, pp.229-259. 
Scott, N., Cooper, C. and Baggio, R., 2008. Destination networks - theory and practice in four Australian cases. Annals of Tourism Research, 35(1), pp.169-188.

Tichy, N.M., Tushman, M.L. and Fombrun, C., 1979. Social network analysis for organizations. The Academy of Management Review, 4(4), pp.507-519.

Vechan, E., 2015. Using social network analysis for civil infrastructure management. In Truax, D. D., Eladaway, I. H., Gude, V., Keith, J., Martin, J. and White, T. (ed.). ProQuest Dissertations Publishing.

Wang, H., Zhang, X. and Lu, W., 2018. Improving Social Sustainability in Construction: Conceptual Framework Based on Social Network Analysis. Journal of Management in Engineering, 34(6), p.05018012.

Wasserman, S., and Faust, K., 1994. Social Network Analysis: Methods and Applications, Cambridge University Press, Cambridge.

Wu, G., Qiang, G., Zuo, J., Zhao, X. and Chang, R., 2018. What are the Key Indicators of Mega Sustainable Construction Projects? -A Stakeholder-Network Perspective. Sustainability, 10(8), p.2939.

Xiaodong, Y., Jiayu, Z. and Xianbo, Z., 2018. Factors Affecting Green Residential Building Development: Social Network Analysis. Sustainability, 10, p.1389.

Xue, H., Zhang, S., Su, Y., Wu, Z. and Yang, R. J., 2018. Effect of stakeholder collaborative management on off-site construction cost performance. Journal of Cleaner Production, 184, pp.490-502.

Yang, R. J., Zou, P. X. W. and Wang, J., 2016. Modelling stakeholder-associated risk networks in green building projects. International Journal of Project Management, 34, pp.66-81.

Yang, R. J. and Zou, P. X. W., 2014. Stakeholder-associated risks and their interactions in complex green building projects: A social network model. Building and Environment, 73, pp.208-222.

Yuan, J., Chen, K., LI, W., JI, C., Wang, Z. and Skibniewski, M. J., 2018. Social network analysis for social risks of construction projects in high-density urban areas in China, Journal of Cleaner Production, 198, pp.940-961.

Zedan, S. and Miller, W., 2017. Using social network analysis to identify stakeholders' influence on energy efficiency of housing. International Journal of Engineering Business Management, 9, pp.1-11.

Zheng, X., Le, Y., Chan, A. P. C., Hu, Y. and Li, Y., 2016. Review of the application of social network analysis (SNA) in construction project management research. International Journal of Project Management, 34, pp.1214-1225. 